\title{
AKTIVITAS ANTIKONVULSAN EKSTRAK RIMPANG TEMU IRENG (Curcuma aeruginosa Roxb.) PADA TIKUS PUTIH JANTAN MENGGUNAKAN ELEKTROKONVULSIOMETER
}

'Agustin Yumita, ${ }^{2}$ Dwitiyanti, ${ }^{3}$ Putri Ermawati

1,2,3 Program Studi Farmasi, FFS, Universitas Muhammadiyah Prof. Dr. Hamka

Info Article

Submitted :

5 November 2021

Revised :

3 Desember 2021

Accepted :

10 Januari 2022

Corresponding Author:

Agustin Yumita

\section{Email :}

agustin_yumita@uhamka.ac.id

\section{ABSTRAK}

Rimpang temu ireng (Curcuma aeruginosa Roxb.) diketahui memiliki kandungan metabolit sekunder yang dapat berkhasiat sebagai antikonvulsan. Penelitian ini bertujuan untuk mengetahui aktivitas antikonvulsan ekstrak etanol $70 \%$ rimpang temu ireng pada tikus putih jantan. Ekstraksi yang digunakan dalam metode ini adalah maserasi. Hewan uji diberi ekstrak etanol $70 \%$ rimpang temu ireng (100 mg/kgBB, $200 \mathrm{mg} / \mathrm{kgBB}$, dan $400 \mathrm{mg} / \mathrm{kgBB})$, pembanding standar asam valproate. Pengujian antikonvulsan menggunakan alat digital elektrokonvulsiometer dengan parameter yang diamati adalah onset HLE dan durasi HLE. Ekstrak etanol 70\% rimpang temu ireng dosis $400 \mathrm{mg} / \mathrm{kgBB}$ memiliki aktivitas yang paling baik sebagai antikonvulsan dengan memperpanjang onset HLE dan mempersingkat durasi HLE sebanding dengan pembanding standar. Temu ireng memiliki potensi untuk dikembangkan sebagai antikonvulsan yang cukup baik.

Kata kunci: Antikonvulsan, Asam valproate, Curcuma aeruginosa

\section{Access this article}

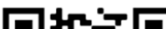

\section{ABSTRACT}

The rhizome of temu ireng (Curcuma aeruginosa Roxb.) is reported to contain bioactive compounds that are useful as anticonvulsants. This study aims to determine the anticonvulsant activity of $70 \%$ ethanol extract of temu ireng rhizome in male white rats. The extraction method used is maceration. Test animals were given $70 \%$ ethanol extract of temu ireng rhizome $(100 \mathrm{mg} / \mathrm{kg}, 200 \mathrm{mg} / \mathrm{kg}$, and $400 \mathrm{mg} / \mathrm{kg}$ ), as a standard comparison with valproic acid. Anticonvulsant testing using a digital electroconvulsiometer with parameters observed were the onset of HLE and the duration of HLE. The $70 \%$ ethanol extract of temu ireng rhizome $400 \mathrm{mg} / \mathrm{kg}$ had the best activity as an anticonvulsant by prolonging the onset of HLE and shortening the duration of HLE comparable to the standard comparator. Temu ireng has the opportunity to be developed as an effective anticonvulsant.

Keywords: Anticonvulsants, Valproic acid, Curcuma aeruginosa 


\section{PENDAHULUAN}

Menurut Global Burden of Disease Study WHO tahun 2010, epilepsi berada diurutan kedua penyakit gangguan neurologis yang banyak diderita di seluruh dunia yang menyebabkan kecacatan. Data WHO tahun 2019 melaporkan bahwa epilepsi meningkat signifikan dan umumnya mempengaruhi kehidupan 50 juta orang di dunia. Populasi terbanyak adalah epilepsi aktif yang membutuhkan pengobatan (WHO, 2019).

Epilepsi merupakan suatu peristiwa paroksismal yang terjadi karena ketidakseimbangan neurotransmiter utama (glutamat dan asam $\gamma$-aminobutyric $(G A B A)$ ) dan neuromodulator (asetilkolin, norepinefrin, dan serotonin) di otak, sehingga mengakibatkan morbiditas yang signifikan bagi penderitanya. Anak-anak dan orang dewasa lebih rentan mengalami epilepsi. Sekitar $1 \%$ dari populasi umum akan mengalami setidaknya satu episode kejang dalam hidup mereka (Dipiro et al, 2015; Jameson et al, 2018).

Walau saat ini sudah ada beberapa terapi pengobatan untuk epilepsi, namun banyak dilaporkan bahwa obat antiepilepsi menimbulkan efek samping yang tidak diharapkan terhadap Sistem Saraf Pusat (SSP) seperti efek kognitif dan efek psikiatri (Cramer et al, 2010). Efek kognitif yang ditimbulkan diantaranya penurunan pada Intelligence Quotients, fungsi memori, kecepatan berfikir dan komunikasi verbal (Lukas dkk, 2016). Masyarakat di Indonesia sering menggunakan obat tradisional sebagai pengobatan alternatif, salah satunya yaitu rimpang temu ireng (Curcuma aeruginosa Roxb.). Famili Zingiberacea dilaporkan memiliki kemampuan sebagai akivitas antikonvulsan yang cukup baik (Venkatanarayana et al, 2013; Hosseini dan Mirazi, 2014).

Curcuma aeruginosa Roxb. dilaporkan mengandung senyawa flavonoid golongan isoflavon (Nugrahaningtyas dkk, 2005), polifenol (Choudhury et al, 2013), dan minyak atsiri (Dosoky dan Setzer, 2019). Banyak laporan positif mengenai senyawa flavonoid yang sering ditemukan terkandung dalam buahbuahan dan sayuran yang dikonsumsi manusia secara teratur, senyawa ini memiliki berbagai aktivitas biologis, baik melalui interaksi dengan target molekuler tertentu dan melalui sifat antioksidannya. Flavonoid diketahui sebagai molekul yang aktif secara biologis bekerja di SPP (Hou et al, 2010), serta berperan dalam stress oksidatif pada epilepsi (Diniz et al, 2015). Dengan demikian, penelitian ini bertujuan untuk melihat aktivitas antikonvulsan dari ekstrak etanol $70 \%$ rimpang temu ireng (Curcuma aeruginosa Roxb.) yang merupakan famili Zingiberaceae terhadap tikus putih jantan (Rattus norvegicus L.) dengan parameter onset HLE (Hind Limb Extension) dan durasi HLE (Hind Limb Extension) menggunakan alat elektrokonvulsiometer.

\section{METODE PENELITIAN}

\subsection{Alat}

Alat yang digunakan dalam penelitian ini yaitu timbangan hewan (Electronic kitchen Scale), neraca analitik (Ohaus), sonde tikus, oven (Memmert oven 
UN55), blender (Philips), ayakan mesh 40 (Bunsekifurui), kandang tikus yang dilengkapi dengan pakan dan minum, stirrer, vacuum rotary evaporator (EYELA N110SWD), waterbath (LOKAL tipe H-WBE$8 \mathrm{~L})$, moisture balance (Mattler Toledo), stopwatch, hot plate (Oxone), chamber, sinar UV box (Camag), alat digital elektrokonvulsiometer (Corchid scientific) dan alat-alat gelas yang digunakan di laboratorium (Pyrex).

\subsection{Bahan}

Bahan yang digunakan dalam penelitian adalah rimpang temu ireng (Curcuma aeruginosa Roxb.) yang diperoleh dan dideterminasi di Unit Konservasi Budidaya Biofarmaka (UKBB) Pusat Studi Biofarmaka Tropika LPPM IPB Bogor (25 Februari 2021). Pelarut etanol $70 \%$ yang digunakan untuk ekstraksi. Depakote $^{\circledast}$ (PT. Abbott Indonesia) sebagai kontrol positif, Na-CMC 0,5\% sebagai kontrol normal, aquadest. Beberapa pereaksi untuk pengujian skrining fitokimia seperti pereaksi Mayer, pereaksi Bouchardat, pereaksi Wagner, pereaksi Dragendrof, pereaksi Liebermann burchard, asam klorida, gelatin, serbuk Mg, $\mathrm{FeCl}_{3}$, asam sulfat pekat. Hewan uji yang digunakan adalah tikus putih jantan (Rattus norvegicus) galur Sprague Dawley yang berumur 2-3 bulan dengan berat badan $\pm 150-250 \mathrm{~g}$ didapatkan dari peternakan di Bogor dan diidentifikasi di Puslit Biologi LIPI (1 April 2021).

\subsection{Metode}

\subsubsection{Pembuatan Simplisia Temu Ireng}

Rimpang segar disortasi basah, kemudian dicuci dengan air mengalir, ditiriskan dan dikeringkan di bawah sinar matahari tidak langsung (ditutupin kain hitam). Rimpang temu ireng yang sudah kering disortasi kembali agar tidak ada pengotor yang tertinggal. Rimpang dihaluskan menggunakan blender, diayak menggunakan ayakan no 40 mesh, ditimbang dan disimpan dalam wadah tertutup rapat (Larasati dan Jusnita, 2020).

\subsubsection{Pembuatan Ekstrak Rimpang Temu Ireng}

Ekstraksi temu ireng menggunakan metode maserasi, serbuk rimpang temu ireng sebanyak $1 \mathrm{~kg}$ direndam dengan pelarut etanol $70 \%$ dalam wadah maserator. Prinsip metode maserasi mengacu pada Farmakope Herbal Indonesia (Kemenkes RI, 2018). Maserat dipisahkan dengan cara filtrasi, kemudian ampas diremaserasi dengan etanol $70 \%$ sebanyak 3 kali. Semua filtrat dikumpulkan dan dipekatkan menggunakan vacuum rotary evaporator dan dilanjutkan ke waterbath hingga diperoleh ekstrak kental. Ekstrak kental temu ireng dihitung persentase rendemennya terhadap simplisia yang digunakan.

\subsubsection{Identifikasi Organoleptik}

Pemeriksaan organoleptik ekstrak rimpang temu ireng (Curcuma aeruginosa Roxb.) meliputi pemeriksaan bentuk, warna, bau dan rasa. Pemeriksaan bentuk dan warna diamati secara visual. Cicipi rasanya dengan mengambil sedikit sarinya dan meletakkannya di lidah untuk menentukan rasanya (Depkes $\mathrm{Rl}, 2000$ ).

\subsubsection{Pemeriksaan Susut Pengeringan}

Pemeriksaan susut pengeringan menggunakan alat moisture balance dengan cara memasukkan ekstrak kental temu ireng kedalam wadah sampel yang terletak di dalam moisture balance dan ratakan. Tutup moisture balance kemudian 
tunggu sampai lampu mati dan catat hasilnya. Pengujian dilakukan sebanyak 3 kali (Depkes RI, 2000).

\subsubsection{Pemeriksaan Kadar Abu}

Ekstrak temu ireng sebanyak $2 \mathrm{~g}$ dimasukan kedalam krus silikat yang telah dipijar dan ditara. Krus silikat berisi ekstrak dipijarkan perlahan kemudian suhu dinaikkan $675^{\circ} \mathrm{C}$ hingga arang habis. Kadar abu total dihitung dan dinyatakan dalam \% b/b (Depkes Rl, 2000).

\subsubsection{Identifikasi Kualitatif Kandungan Kimia Ekstrak Etanol $\mathbf{7 0 \%}$ Temu Ireng}

Ekstrak etanol 70\% temu ireng diidentifikasi dengan beberapa pereaksi seperti yang tercantum dalam Hanani (2014). Senyawa yang diidentifikasi adalah alkaloid, flavonoid, fenolik, tannin, saponin, terpenoid dan steroid. Golongan alkaloid diidentifikasi menggunakan pereaksi Dragedorrf, Mayer, Bouchardat dan Wagner. Identifikasi flavonoid dengan uji shinoda, fenolik diidentifikasi menggunakan besi (III) korida dan identifikasi tannin dengan gelatin. Identifikasi terpenoid/steroid menggunakan pereaksi Liebermann Burchard dan Salkowski.

\subsubsection{Penetapan Dosis Sediaan Uji dan Pembanding $\mathbf{7 0 \%}$}

Penelitian ini menggunakan 3 variasi dosis yang didasarkan pada penelitian sebelumnya Venkatanarayana et al. (2013) yakni $100 \mathrm{mg} / \mathrm{kgBB}, 200 \mathrm{mg} / \mathrm{kgBB}, 400$ $\mathrm{mg} / \mathrm{kgBB}$. Sediaan suspensi etanol $70 \%$ rimpang temu ireng dibuat dengan cara mensuspensikan ekstrak dengan Na-CMC $0,5 \%$ sebagai pensuspensi. Satu tablet Depakote $^{\circledast}$ mengandung $250 \mathrm{mg}$ sodium hydrogen divalproate. Tablet Depakote ${ }^{\circledR}$ digerus hingga halus, ditimbang sebanyak $5 \mathrm{mg}$, disuspensikan dengan Na-CMC 0,5\% hingga homogen, dicukupkan dengan aquades hingga volume $25 \mathrm{~mL}$.

\subsubsection{Pengelompokkan Hewan Uji}

Pengujian ini telah mendapat persetujuan Komisi Etik Penelitian Kesehatan Universitas Muhammadiyah Prof. Dr. Hamka (KEPK-UHAMKA) No. 02/21.05/01024 tertanggal 17 Maret 2021. Penelitian ini menggunakan metode Rancangan Acak Lengkap (RAL), berdasarkan rumus Federer diketahui jumlah hewan coba yang dibutuhkan sebanyak 25 ekor tikus putih jantan. Dalam penelitian ini terdiri dari 5 kelompok yakni kelompok normal diberikan suspensi $\mathrm{Na}$ CMC 0,5\%. Kelompok kontrol positif diberikan suspensi Depakote ${ }^{\circledR}$. Kelompok uji menggunakan dosis dari penelitian Venkatanarayana et al., (2013) dengan sedikit modifikasi (dosis $100 \mathrm{mg} / \mathrm{kgBB}, 200$ $\mathrm{mg} / \mathrm{kgBB}, 400 \mathrm{mg} / \mathrm{kgBB}$ ). Masing-masing kelompok terdiri dari 5 ekor tikus putih jantan.

\subsubsection{Pengujian Antikonvulsan dengan Alat Elektrokonvulsiometer}

Hewan coba yang sudah dikelompokkan kemudian diaklimatisasi selama 7 hari di laboratorium hewan. Aklimatisasi bertujuan agar hewan uji dapat beradaptasi dengan lingkungan baru serta menghindari stress. Hewan diberi pakan dan minum, serta kandang yang bersih dan nyaman. Pengamatan dilakukan terhadap keadaan umum dan penimbangan berat badan hewan uji dilakukan setiap hari.

Sampel uji diberikan kepada semua kelompok hewan percobaan 1 jam 
sebelum diinduksi electroshock. Hewan uji kelompok kontrol positif diberikan suspensi Depakote ${ }^{\oplus}$ dengan dosis 1,5417 $\mathrm{mg} / \mathrm{kg}$, kelompok kontrol normal diberikan $\mathrm{Na}$-CMC 0,5\%, kelompok uji 1 diberikan ekstrak etanol $70 \%$ rimpang temu ireng dengan dosis $100 \mathrm{mg} / \mathrm{kgBB}$, kelompok uji 2 diberikan ekstrak etanol $70 \%$ rimpang temu ireng dengan dosis 200 $\mathrm{mg} / \mathrm{kgBB}$, kelompok uji 3 diberikan ekstrak etanol $70 \%$ rimpang temu ireng dengan dosis $400 \mathrm{mg} / \mathrm{kgBB}$. Elektroda diaplikasikan pada kedua telinga hewan uji dengan electroshock berkekuatan 150 mAmp dan 50 hertz selama 0,2 detik yang bertujuan untuk menginduksi kejang. Parameter yang dilihat dalam pengamatan ini yaitu onset HLE (Hind Limb Extention) dan durasi HLE (Hind Limb Extention). HLE (Hind Limb Extention) adalah kejadian saat kaki depan dan kaki belakang tikus merenggang (Mudium dan Kolasani, 2014).

\subsection{Analisis Data}

Data onset HLE (Hind Limb Extention) dan durasi HLE (Hind Limb Extention) diolah secara statisik menggunakan SPSS IBM 24.0. Data selanjutnya dianalisis dengan One Way Anova dan dilanjutkan uji Tukey . Nilai $\mathrm{P}<0,05$ dianggap signifikan.

\section{HASIL DAN PEMBAHASAN}

Tabel 1. Karakteristik Ekstrak Etanol 70\% Temu Ireng (Curcuma aeruginosa Roxb.)

\begin{tabular}{lc}
\hline Karakteristik Fisik - Kimia & Hasil \\
\hline Organoleptik & \\
Bentuk & Ekstrak Kental \\
Warna & Cokelat tua \\
Bau & Khas \\
Rasa & Pahit \\
\hline
\end{tabular}

Rimpang temu ireng diekstraksi dengan metode maserasi menggunakan pelarut etanol $70 \%$ dengan persentase rendemen yang diperoleh terhadap simplisia sebesar 14,00\%. Pelarut etanol memiliki kemampuan dalam menarik senyawa aktif tanin, polifenol, poliasetilen, flavanol, terpenoid, sterol dan alkaloid (Pandey dan Tripathi, 2014).

Pengamatan organoleptik bertujuan untuk mengetahui karakteristik ekstrak etanol $70 \%$ rimpang temu ireng yang meliputi bentuk, warna, rasa, dan bau. Hasil dalam penelitian ini (Tabel 1) yang didapatkan menunjukkan bahwa hasil sesuai dengan Farmakope Herbal Indonesia Edisi 2 Tahun 2018 yakni berupa ekstrak kental, warna cokelat tua, bau khas dan rasa pahit.

Hasil pemeriksaan susut pengeringan (Tabel 1) dengan menggunakan alat moisture balance sebesar 7,22\%. Nilai susut pengeringan kurang dari $10 \%$ meminimalkan pertumbuhan jamur dan kapang serta meningkatkan umur simpan dan meningkatkan mutu ekstrak (Zainab dkk, 2016). Kadar abu dilakukan dengan tujuan untuk mengetahui jumlah komponen anorganik atau mineral yang tersisa setelah proses pengabuan. Hasil pengujian kadar abu ekstrak etanol 70\% rimpang temu ireng sebesar 7,3628 \%. 


\begin{tabular}{lc}
\hline Rendemen Ekstrak & $14,00 \%$ \\
Susut pengeringan & $7,22 \%$ \\
Kadar Abu & $7,36 \%$ \\
\hline
\end{tabular}

Tabel 2. Hasil Identifikasi Kualitatif Kandungan Kimia Ekstrak Etanol 70\% Temu Ireng

\begin{tabular}{clc}
\hline No. & Senyawa yang diidentifikasi & Ekstrak Etanol 70\% \\
\hline 1. & Alkaloid & + \\
2. & Flavonoid & + \\
3. & Fenolik & + \\
4. & Saponin & + \\
5. & Tanin & + \\
6. & Terpenoid & + \\
7. & Steroid & + \\
\hline
\end{tabular}

\section{Keterangan:}

+ :Teridentifikasi mengandung senyawa

- : :Tidak teridentifikasi mengandung senyawa

Identifikasi kandungan kimia dilakukan untuk mengetahui golongan senyawa yang terkandung dalam ekstrak etanol 70\% rimpang temu ireng (Curcuma aeruginosa Roxb.) dengan menggunakan pereaksi warna. Hasil identifikasi menunjukkan bahwa ekstrak etanol $70 \%$ temu ireng positif mengandung alkaloid, flavonoid, fenolik, saponin, tanin, terpenoid dan steroid (Tabel 2). Famili Zingiberaceae dilaporkan mengandung senyawa flavonoid, fenilpropanoid, terpenoid, seskuiterpen (Simoh dan Zainal, 2015; Lakshmi et al, 2011; Lai et al, 2004). Rimpang temu ireng (Curcuma aeruginosa Roxb.) dilaporkan mengandung flavonoid golongan isoflavon (Nugrahaningtyas dkk, 2005), alkaloid, tannin, dan saponin (George et al, 2014), minyak atsiri (8,9dehydro-9-formyl - cycloisolongifolene, dihydrocostunolide (Kamazeri et al, 2012),

curzerenone, germacrone (Theanphong dan Mingvanish, 2017), curcumenol, and $\beta$ pinene, camphor, curcumenol, $\beta$-Pinene, germacrone isoborneol, curzerene dan germacrene B) (Angel et al, 2014; Dosoky dan Setzer, 2019).

Penelitian ini menggunakan hewan uji tikus putih jantan dikarenakan mudah dipelihara dan tikus putih jantan umumnya tidak terlalu agresif serta memiliki aktivitas hormonal yang lebih stabil dibandingkan dengan tikus putih betina. Metode pengujian antikonvulsan menggunakan alat digital elektrokonvulsiometer. Alat ini memiliki kemampuan menginduksi kejang secara maksimal pada hewan uji dengan kekuatan 50 mAmp selama 0,2 detik (Fisseha et al, 2021). 
Tabel 3. Hasil Rata-Rata Onset HLE

\begin{tabular}{lccccc}
\hline & \multicolumn{5}{c}{ Onset HLE (detik) } \\
\cline { 2 - 6 } Kelompok & Kontrol Positif & Kontrol Normal & Dosis Uji 1 & Dosis Uji 2 & Dosis Uji 3 \\
\hline Tikus 1 & 9 & 4 & 3 & 5 & 10 \\
Tikus 2 & 6 & 2 & 6 & 7 & 7 \\
Tikus 3 & 11 & 4 & 4 & 4 & 9 \\
Tikus 4 & 7 & 5 & 5 & 5 & 5 \\
Tikus 5 & 9 & 3 & 4 & 6 & 8 \\
Rata-rata \pm SD & $8,4 \pm 1,94$ & $3,6 \pm 1,14$ & $4,4 \pm 1,14$ & $5,4 \pm 1,14$ & $7,8 \pm 1,92$ \\
\hline
\end{tabular}

Tabel 4. Hasil Rata-Rata Durasi HLE

\begin{tabular}{lccccc}
\hline & \multicolumn{5}{c}{ Durasi HLE (detik) } \\
\cline { 2 - 6 } Kelompok & Kontrol Positif & Kontrol Normal & Dosis Uji & Dosis Uji & Dosis Uji \\
& & & $\mathbf{1}$ & $\mathbf{2}$ & $\mathbf{3}$ \\
\hline Tikus 1 & 9 & 37 & 22 & 24 & 11 \\
Tikus 2 & 11 & 33 & 26 & 15 & 7 \\
Tikus 3 & 7 & 26 & 13 & 8 & 9 \\
Tikus 4 & 14 & 32 & 28 & 18 & 8 \\
Tikus 5 & 8 & 29 & 19 & 21 & 17 \\
Rata-rata \pm SD & $9,8 \pm 2,77$ & $31,4 \pm 4,15$ & $21,6 \pm 5,94$ & $17,2 \pm 6,14$ & $10,4 \pm 3,97$ \\
\hline
\end{tabular}

Hasil uji normalitas data dengan uji one sample Kolmogorov-Smirnov dan uji homogenitas dianalisis dengan Test of Homogenity Variances diperoleh $p>0,05$ yang menunjukkan bahwa data yang diperoleh terdistribusi normal dan bervariasi homogen, kemudian analisa statistik dilanjutkan dengan uji ANOVA satu arah yang dimaksudkan untuk mengetahui apakah ada perbedaan yang bermakna pada setiap kelompok perlakuan dengan ketentuan $p<0,05$.

Hasil analisa uji ANOVA yang didapatkan dilanjutkan dengan uji Tukey yang bertujuan untuk mengetahui kelompok mana yang memiliki perbedaan signifikan atau tidak antar kelompok. Berdasarkan uji Tukey pada data onset HLE dan durasi HLE hasil yang diperoleh menunjukkan bahwa dari kelima kelompok perlakuan memiliki perbedaan respon. Analisa uji Tukey pada data onset HLE (Tabel 3) menunjukkan bahwa kontrol normal sebanding dengan dosis uji 1 dan dosis uji 2. Dosis uji 3 sebanding dengan kontrol positif. Respon yang paling tinggi dalam memperpanjang onset HLE ditunjukkan oleh kelompok uji dosis 3 yaitu 7,8 \pm 1,92 detik sebanding dengan kelompok kontrol positif yaitu 8,4 $\pm 1,94$ detik $(p<0,05)$.

Pada analisa uji Tukey pada data durasi HLE (Tabel 4) menunjukkan bahwa kontrol positif sebanding dengan dosis uji 3. Dosis uji 2 sebanding dengan dosis uji 1. Kontrol normal tidak sebanding dengan kelompok manapun. Respon yang paling tinggi dalam mempersingkat durasi HLE ditunjukkan oleh kelompok uji dosis 3 yaitu 10,4 $\pm 3,97$ detik sebanding dengan kelompok kontrol positif yaitu 9,8 $\pm 2,77$ $\operatorname{detik}(p<0,05)$. 


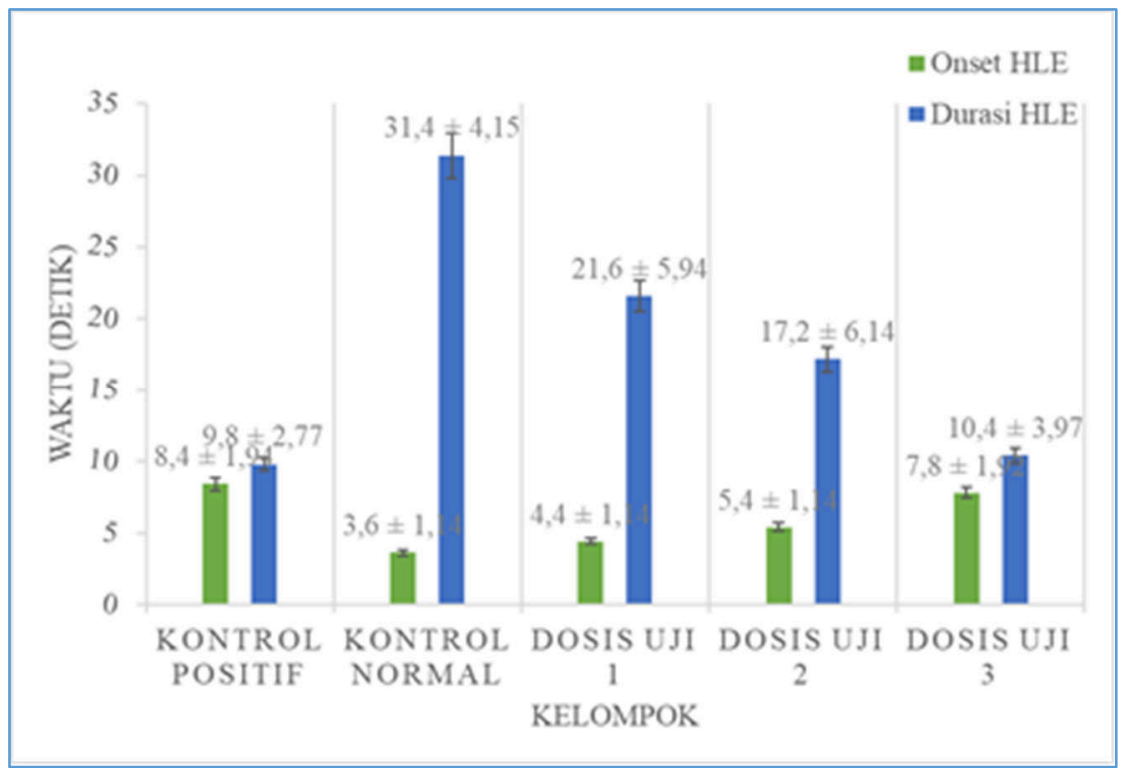

Gambar 1. Grafik Rata-Rata Onset HLE dan Durasi HLE (detik)

Grafik pada Gambar 1 menunjukkan bahwa semakin besar dosis ekstrak etanol 70\% rimpang temu ireng yang diberikan pada tikus mampu memperlama onset HLE dan mempersingkat durasi HLE. Dari hasil analisa statistik yang dilakukan menunjukkan bahwa variasi ketiga dosis ekstrak etanol $70 \%$ rimpang temu ireng dapat memberikan efek sebagai antikonvulsan yang berbeda-beda. Kelompok dosis uji ke 3 (400 mg/KgBB) dapat memperlama onset HLE dan mempersingkat durasi HLE yang sebanding dengan kontrol positif (Depakote) dibandingkan dengan kelompok dosis uji 1 (100 mg/KgBB), kelompok dosis uji ke 2 (200 mg/KgBB) serta kelompok normal.

Berdasarkan penelitian yang dilakukan Venkatanarayana et al. (2013) melaporkan bahwa ekstrak etanol Zingiber officinale memiliki kemampuan sebagai antikonvulsan pada dosis $200 \mathrm{mg} / \mathrm{Kg}$ pada tikus swiss albino yang efeknya sebanding dengan standar fenitoin. Begitu pula dengan penelitian yang dilakukan Hosseini dan Mirazi (2015) ekstrak hidroetanol Zingiber officinale yang diberikan pada tikus jantan yang diinduksi PTZ menunjukkan bahwa ekstrak tersebut memiliki efek antikonvulsan.

Rimpang temu ireng (Curcuma aeruginosa Roxb.) dilaporkan mengandung flavonoid (Nugrahaningtyas dkk, 2005) dan polifenol (Choudhury et al, 2013) yang memungkinkan memberikan aktivitas antiepilepsi dengan memodulasi kompleks saluran GABAA-Cl, karena secara struktural mirip dengan benzodiazepin (Choudhury et al, 2011). Penelitian yang dilakukan Guo et al. (2011) pada pemberian ekstrak etanol Abelmoschus manihot yang mengandung flavonoid seperti isoquercitrin, quercetin-3'-Oglucoside, quercetin, hyperoside, hibifolin menunjukkan ketiga dari senyawa tersebut terdeteksi terdapat di dalam otak hewan uji setelah pemberian sampel ekstrak dalam pengujian aktivitas antikonvulsan dan antidepresant. 
Dalam penelitian ini, pengujian hanya dilakukan terhadap ekstrak etanol $70 \%$ temu ireng sehingga perlu dibuat berbagai fraksi ekstrak yang selanjutnya diuji aktivitas antikonvulsan menggunakan alat digital elektrokonvulsiometer. Parameter pengujian aktivitas antikonvulsan pada range batas onset HLE diperlukan lebih lama. Fraksi ekstrak yang memberikan aktivitas terbaik dilanjutkan untuk diisolasi, diidentifikasi dan dikarakterisasi untuk mengetahui senyawa aktif yang bertanggung jawab dalam aktivitas antikonvulsan.

\section{KESIMPULAN}

Aktivitas antikonvulsan tertinggi pada ekstrak etanol $70 \%$ rimpang temu ireng (Curcuma aeruginosa Roxb.) ditunjukkan pada dosis III (400 mg/kg BB) dengan onset HLE terlama (7,8 detik) dan durasi HLE paling singkat (10,4 detik) yang sebanding dengan asam valproat (Depakote). Dengan demikian, temu ireng berpotensi digunakan sebagai terapi antikonvulsan dimasa mendatang dengan studi lanjutan melalui pemeriksaan aktivitas antikonvulsan terhadap berbagai fraksi ekstrak serta perlu dilakukan isolasi senyawa aktif yang memiliki aktivitas antikonvulsan.

\section{UCAPAN TERIMA KASIH}

Tim penulis mengucapkan terima kasih kepada Dekan Fakultas Farmasi dan Sains Universitas Muhammadiyah Prof. Dr. Hamka Bapak Dr. apt. Hadi Sunaryo, M.Si yang telah memberikan ijin dalam melakukan penelitian di Laboratorium Terpadu sehingga penelitian ini dapat berjalan dengan lancar.

\section{DAFTAR PUSTAKA}

Angel GR, Menon N, Vimala B, dan Nambisan B. (2014). Essential Oils Composition of Eight Starchy Curcuma Species. Industrial Crops and Products. 60:233-238.

Choudhary N, Bijjem KRV, dan Kalia AN. (2011). Antiepileptic Potential of Flavonoids Fraction From The Leaves of Anisomeles malabarica. Journal Of Ethnopharmacology. 135(2): 238-242.

Choudhury D, Ghosal M, Das AP, dan Mandal P. (2013). Development os Single Node Cutting Propagation Techniques And Evaluation of Antioxidant Activity of Curcuma aeruginosa Roxburgh Rhizome. International Journal Of Pharmacy and Pharmaceutical Sciences. 5(2).

Cramer JA, Mintzer S, Wheless J, dan Mattson RH. (2010). Adverse Effects of Antiepileptic Drugs : a Brief Overview Of Important Issues. Expert Review of Neurotherapeutics. 10(6): 885-891.

Departemen Kesehatan RI. (2000). Parameter Standar Umum Ekstrak Tumbuhan Obat. Edisi IV. Departement Kesehatan Republik Indonesia. Jakarta. HIm. 31.

Diniz TC, Silva JC, Lima-Saraiva SRG, Ribeiro FPR de A, Pacheco AGM, Freitas RM, QuintansJunior LJ, Quintans J de SS, Mendes RL, dan Almeida JRG da S. (2015). The Role of Flavonoids On Oxidative Stress in Epilepsy. Oxidative Medicine and Cellular Longevity. 2015:1-9.

Dipiro JT, Schwinghammer TL, dan Wells BG. (2015). Pharmacotherapy Handbook $9^{\mathrm{Ed}}$. McGraw-Hill Education Companies, New York. HIm 518, 529.

Dosoky N, dan Setzer WN. (2018). Chemical Composition and Biological Activities of Essential Oils of Curcuma Species. Nutrients. 10(9): 1196.

Fisseha N, Shibeshi W, dan Bisrat D. (2021). Evaluation Of Anticonvulsant Activity Of 80\% Methanolic Root Bark Extract and Solvent Fractions of Pentas schimperiana (A. Rich) Vatke (Rubiaceae) in Swiss Albino Mice. Advances in Pharmacological and Pharmaceutical Sciences. 2021:1-7.

George M, Britto SJ, dan Arulappan T. (2014). Pharmacognostic and Phytochemical Evaluation of Curcuma aeruginosa Roxb. 
World Journal Of Pharmaceutical Research. 3 (9): 1042-1057.

Guo J, Xue C, Duan JA, Qian D, Tang Y dan You Y. (2011). Anticonvulsant, Antidepressantlike Activity of Abelmoschus manihot Ethanol Extract And Its Potential Active Components In Vivo. Phytomedicine. 18:14: 1250-1254.

Hanani, E. (2015). Analisis Fitokimia. EGC. Jakarta.

Hosseini A, dan Mirazi N. (2014). Acute Administration of Ginger (Zingiber officinale rhizomes) Extract On Timed Intravenous Pentylenetetrazol Infusion Seizure Model in Mice. Epilepsy Research. 109(3):411-9.

Hosseini A, dan Mirazi N. (2015). Alteration of Pentylenetetrazole-induced Seizure Threshold by Chronic Administration of Ginger (Zingiber officinale) Extract in Male Mice. Pharmaceutical Biology. 53(5):752-7.

Hou Y, Aboukhatwa MA, Lei DL, Manaye K, Khan I, dan Luo Y. (2010). Anti-depressant Natural Flavonols Modulate BDNF and Beta Amyloid in Neurons And Hippocampus Of Double TgAD Mice. Neuropharmacology. 58(6):911-20.

Jameson JL, Kasper DL, Longo DL, Fauci AS, dan Hauser SL. (2018). Harrison's Principles of Internal Medicine $20^{\text {th }}$ Edition. McGraw-Hill Education. New York.

Kamazeri TSAT, Samah OA, Taher M, Susanti D, dan Qaralleh H. (2012). Antimicrobial Activity and Essential Oils of Curcuma aeruginosa, Curcuma mangga, and Zingiber cassumunar from Malaysia. Asian Pasific Journal of Tropical Medicine. 5(3): 202-209.

Kementerian Kesehatan RI. (2018). Farmakope Herbal Indonesia $\|^{\text {ed. }}$ Kementerian Kesehatan Republik Indonesia. Jakarta. HIm. 531.

Lai EY, Chyau CC, Mau JL, Chen CC, Lai YJ, dan Shih CF. (2004). Antimicrobial Activity and Cytotoxicity of The Essential Oil of Curcuma zedoaria. The American Journal of Chinese Medicine. 32: 281-290.

Lakshmi S, Padmaja G. dan Remani P. (2011). Antitumour Effects of Isocurcumenol Isolated from Curcuma zedoaria Rhizomes on Human and Murine Cancer Cells. International Journal of Medicinal Chemistry. 2011: 1-13.
Larasati SP, dan Jusnita N. (2020). Nanoemulsion Formulation of Turmeric Extract (Curcuma longa L.) As an Antioxidant. Journal Of Pharmaceutical and Sciences (JOS). 3 (1): 33-41.

Lukas A, Harsono, dan Astuti. (2016). Gangguan Kognitif Pada Epilepsi. Berkala IImiah Kedokteran Duta Wacana. 1(2): 144152.

Mudium R, dan Kolasani B. (2014). Anticonvulsant Effect of Hydroalcoholic Seed Extract of Croton Tiglium in Rats and Mice. Journal of Clinical and Diagnostic Research 8(3): 24-26.

Nugrahaningtyas KD, Matsjeh S, dan Wahyuni TD. (2005). Isolasi dan Identifikasi Senyawa Flavonoid dalam Rimpang Temu Ireng (Curcuma aeruginosa Roxb.). Biofarmasi. 3(1): 32-38.

Pandey, A, dan Tripathi S. (2014). Concept of Standardization, Extraction and Pre Phytochemical Screening Strategies For Herbal Drug. Journal of Pharmacognosy and Phytochemistry. 2(5):115-119.

Simoh S, dan Zainal A. (2015). Chemical Profiling of Curcuma aeruginosa Roxb. Rhizome Using Different Techniques of Solvent Extraction. Asian Pasific Journal of Tropical Biomedicine. 5(5): 412-417.

Theanphong O, dan Mingvanish W. (2017). Chemical Constituents and Antioxidants Activities of Essential Oils from Roots and Rhizomes of Curcuma alismatifolia Gagnap From Thailand. The Journal of Applied Science. 16(Special Issue):105-111.

Venkatanarayana N, Basha MG, Pokala N, Jayasree T, John SP, dan Nagesh C. (2013). Evaluation Of Anticonvulsant Activity of Ethanolic Extract of Zingiber officinale in Swiss Albino Rats. Journal of Chemical and Pharmaceutical Research. 5(9): 60-64.

World Health Organization. (2019). Epilepsy. (Diakses tanggal 3 November 2021). Available : https://www.who.int/newsroom/fact-sheets/detail/epilepsy

Zainab, Sulistyani N, dan Anisaningrum. (2016). Penetapan Parameter Standarisasi Non Spesifik dan Spesifik Ekstrak Daun Pacar Kuku (Lawsonia inermis L.). Media Farmasi. 13 (2):212-226. 


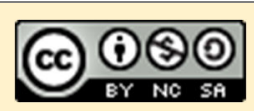

Copyright 02020 The author(s) You are free to Share - copy and redistribute the material in any medium or format. Adapt - remix, transform, and build upon the material. manner, but not in any way that suggests the licensor endorses you or your use. NonCommercial - You may not use the material for commercial purposes. ShareAlike - If you remix, transform, or build upon the material you must distribute your contributions under the same license as the original. No additional restrictions - You may not you remix, transform, or build upon the material, you must distribute your contributions under the same license as the
apply legal terms or technological measures that legally restrict others from doing anything the license permits. 